\title{
Teacher Self-Evaluation Models As Authentic Portfolio To Monitor Language Teachers' Performance
}

\author{
Singgih Widodo \\ Politeknik Ubaya, Surabaya
}

\begin{abstract}
Many principals or heads of English departments usually use supervising checklists to monitor or evaluate their teachers' performance. As a matter of fact, teachers may not feel satisfied with the feedback they have got from their superiors. This paper aims at inspiring them with ideas of self-learning to improve their own teaching performance for professional development. In this paper, the writer would like to share his own experience as a principal and a head of the English department by exploring self-evaluation models to monitor language teachers' performance in the classroom. For this purpose, it is necessary to identify the needs of language teachers and later this teacher portfolio may also help principals or head of the department evaluate their teachers' performance.
\end{abstract}

Key words: Self-evaluation, feedback, reflection, teacher-diary, teacher portfolio, teacher performance

This paper aims at inspiring especially language teachers as well as language supervisors or principals with fruitful ideas on teacher selfevaluation models as teacher portfolio to monitor language teachers' performance. This teacher portfolio is used as evidence of what the teachers are able to do and how they do it. The collection of the teacher's work as portfolio depends on how the portfolio will be used and what the purposes of the portfolio will be. As a matter of fact, portfolio is useful for both language teachers and their supervisors/principals 
The aim of using portfolio for language teachers is to raise the awareness of becoming reflective teachers, to develop independent, selfdirected learner-teachers, and to achieve the best performance for their teaching effectiveness. The aim of using portfolio for language supervisors or school principals is to provide alternative ways to evaluate both products and processes of the teachers' learning and teaching efforts and to facilitate the professional development of the language teachers. The teacher portfolio is authentic and more objective data for school principals or language supervisors to use better judgments or decisions for their teachers. Therefore, teacher portfolio could be as alternative ways to overcome the shortcomings of the subjectivity of the traditional teacher evaluation which lacks authentic evidence of their teachers' performance or efforts.

Further, it is expected that language teachers become self-directed learners as well as researchers by using teacher self-evaluation models to improve their own teaching performance. This activity will also help teachers become more critical and aware of their actions and values given to their students. These critical behavior and awareness of doing their best in class would enhance the teacher professional development. By using this portfolio, it would also help language teachers step their own ladder career as academics as well as professionals.

Moreover, it is advisable that language teachers choose their preferred self-evaluation model to monitor and improve their own performance in class. Therefore, this paper would discuss some instruments of teacher self-evaluation model, that is teacher self-evaluation, students feedback, peer observation feedback, teacher reflection and teacher diary, and teacher self-evaluation models, advantages of using teacher portfolio and the results of the survey.

\section{INSTRUMENTS OF TEACHER SELF-EVALUATION MODELS}

Language teachers may monitor their own teaching performance by using teacher portfolio. In order to get more objective information on their performance, they use some instruments, such as teacher self-evaluation, students' feedback, peer-observer feedback, teacher reflection, and teacher diary. Here, the writer would like to suggest these five instruments of teacher portfolio as follows :
First, teacher self-evaluation is used as an instrument for evaluating teachers' performance. After teaching sessions in the classroom, language teachers could use self-evaluation checklists they need. Some alternatives of self-evaluation checklists (see the appendix) are designed by Gibbs and Habeshaw (1989: 217), Margot Cameron Jones (1991: 48), and John Partington and Patricia Luker (1984). The self-evaluation checklist is used by language teachers to reflect upon their teaching performance. The teachers may also ignore the unnecessary items in the questionnaire and add other necessary items or modify the self-evaluation checklists.

Second, students feedback could also be used as a monitoring instrument for the teacher self-evaluation to enhance the objectivity of the feedback. In order to get students feedback, language teachers ask their students to fill out questionnaires which have the same items as teacher self-evaluation checklists. The students are supposed to fill out the questionnaires directly after the teaching session. Students feedback may become most important inputs for the teachers to improve their teaching performance. By analyzing the students' feedback, teachers could know the needs of their students on their teacher performance in the classroom.

Third, peer-observer feedback is used to monitor language teachers performance in the classroom. In order to be able to give feedback, the peer-observers (colleagues) could be asked to sit in the classroom and observe the teaching and leaming process. The peer-observers use their evaluation checklists having the same items as the teacher self-evaluation checklists. It is advisable that the peer-observer is also the same language teacher who could give feedback by conducting classroom observation. In order to be able to give objective feedback, he/she should have enough knowledge/skills and experience in language teaching and know how to conduct classroom observation. Allwright (1988) stated that what is involved in classroom observation is a procedure for keeping a record of classroom events in such a way that can be studied later, typically either for teaching training or for research purposes. Further, Arends (1998) also explained that observation as a research procedure in which the researcher watches and records behaviors: a procedure for leaming to teach by watching, recording and reflecting about teacher and student behavior in a classroom. Based on Allwright and Arends points of view, it can be concluded that in classroom observation, an observer has to do at least three 
important things :

1. sitting in a classroom watching on the teaching performance as well as the students' behavior

2. recording what have happened in the classroom

3. reflecting/discussing between the observer and the observee about teacher performance in the classroom as well as students behavior.

From this kind of developmental observation, an observe may receive constructive feedback that may lead him / her to the development of his/her own teaching performance.

Fourth, reflection is careful and analytical thought by teachers about what they are doing and the effects of their behavior on their instruction and on student learning (Arends, 1998: 536). Reflection means that teachers have to think and analyze what they have done/taught in the classroom by relating to their previous experiential knowledge and received knowledge. Relating to the teacher portfolio, language teachers can use several ways to do teaching reflection by using the results of their self-evaluation checklist, their students feedback, and their peer-observer feedback. In this matter, the language teachers may discuss with their colleagues peers as observers and with some students about what they have seen on the teaching session. The idea behind this reflection is that language teachers could ask their peer observers/students to express their thoughts, impression, feelings, and experience about teachers' performance they have just seen in the classroom.

Further, this reflection might be used to develop the power of critique. Therefore, it is important to have an alternative reflective model for language teachers (Wallace, 1993) as can be seen in Figure 1

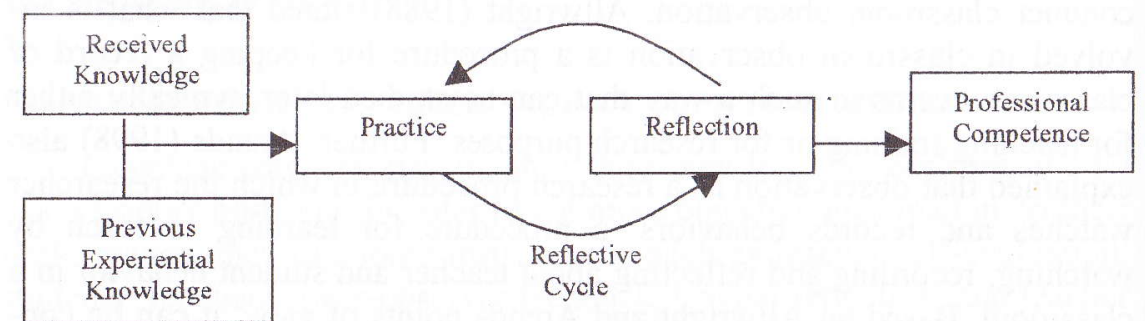

Figure 1. A Reflection Model for Language Learners
Fifth, a teacher diary can be used as a way to note feedback relating to language teachers' performance in the classroom. A teacher diary may contain important information about teachers' performance such as the weaknesses of the teachers in relating to their teaching performance in the classroom or same teaching performance that should be changed, the students' expectations to understand the lesson better, and so on. Further, a teacher diary could be as a useful tool for both classroom research and personal professional development. Arends (1998) stated that one of the most productive ways to enhance reflective thinking is by using a diary/journal. The results of the teacher reflection could also be put in the diary. This idea is inspired by Halbach's successful research on using trainees' diaries to evaluate a teacher training course (Halbach in ELT journal, 1999: 183-189). She described how teacher-trainees' diaries were used as a source of information about teacher-trainees' perception of a course in methodology. And the aim of the course was to provide the teacher-trainees with the opportunity to be aware of their own perception of teaching and to modify and enrich them through the perception of new ideas. Morcover, Elliot (1991) commented that a teacher diary could contain observation, feelings, reactions, interpretation, reflection explanations altogether, then, as a potential rich research tool. Thus, by using a teacher diary, a language teacher could become a researcher of his own teaching performance as well.

\section{THE ADVANTAGES OF USING TEACHER PORTFOLIO OF SELF- EVALUATION MODELS :}

- facilitating the professional development of language teachers by monitoring teachers' performance in the classroom in order to improve their teaching performance

- providing evidence of rich and authentic information and evidence of growth of the language teachers that may be used for teachers' career promotion

- giving the opportunity for the language teachers to use the teacher portfolio of self-evaluation models as a part of their classroom research

- developing the language teachers themselves to become independent, self-directed and autonomous teacher learners 
- providing an alternative way to evaluate both products and processes of teachers' learning attempts

- giving a holistic profile of what the language teachers are able to do and how they are able to do it

Moreover, the teacher self-evaluation models could function as authentic teacher portfolios for the language teachers to show their actual efforts, progress, and achievements. In order to be authentic portfolio, the teachers have to use/implement the teacher self-evaluation models again and again within a period of time, for example, several times in one semester or one academic year. The more they try out or use them, the more information the teachers may obtain. The benefits of these self-evaluation

Table 1. Teacher Self-Evaluation Models To Monitor Teacher Performance in The Classroom

\begin{tabular}{|c|c|c|c|}
\hline No & $\begin{array}{c}\text { Alternative } \\
\text { Models }\end{array}$ & How to use & Rationale \\
\hline 1 & $\begin{array}{l}\text { Teacher } \\
\text { Self- } \\
\text { Evaluation } \\
+ \text { Teacher } \\
\text { Reflection }\end{array}$ & $\begin{array}{l}\text { After a teaching session, the teacher } \\
\text { would fill out the self-evaluation } \\
\text { checklist and then he/she would } \\
\text { think hard and analyze what he/she } \\
\text { has just taught with the received } \\
\text { knowledge and previous experien- } \\
\text { tial knowledge in order to improve } \\
\text { his/her teaching performance in the } \\
\text { future }\end{array}$ & $\begin{array}{l}\text { using a teacher self- } \\
\text { evaluation checklist } \\
\text { as a tool for teacher } \\
\text { reflection } \\
\text { any individual } \\
\text { teacher could do this } \\
\text { alone whenever } \\
\text { he/she needs after a } \\
\text { teaching session }\end{array}$ \\
\hline 2 & $\begin{array}{l}\text { Teacher } \\
\text { Self- } \\
\text { Evaluation } \\
+ \text { Students } \\
\text { feedback + } \\
\text { Teacher Re- } \\
\text { flection }\end{array}$ & $\begin{array}{l}\text { After a teaching session, the teacher } \\
\text { would fill out the self-evaluation } \\
\text { checklist and also ask students to } \\
\text { give feedback by filling out the } \\
\text { same checklists and then he/ she } \\
\text { would look at the students feedback } \\
\text { and compare it with his/her self- } \\
\text { evaluation and analyze them with } \\
\text { the received knowledge and previ- } \\
\text { ous experiential knowledge in order } \\
\text { to improve his/her teaching per- } \\
\text { formance in the future. }\end{array}$ & $\begin{array}{l}\text { Students feedback is } \\
\text { the most important } \\
\text { input because stu- } \\
\text { dents are the teach- } \\
\text { ers' direct customers } \\
\text { Using students' } \\
\text { feedback and teacher } \\
\text { self-evaluation as a } \\
\text { tool for teacher re- } \\
\text { flection }\end{array}$ \\
\hline
\end{tabular}

\begin{tabular}{|c|c|c|c|}
\hline 3 & $\begin{array}{l}\text { Teacher } \\
\text { Self-Evalu- } \\
\text { ation + Stu- } \\
\text { dents' feed- } \\
\text { back + peer- } \\
\text { observer } \\
\text { feedback + } \\
\text { Teacher Re- } \\
\text { flection }\end{array}$ & $\begin{array}{l}\text { After a teaching session, the teacher } \\
\text { would fill out the self-evaluation } \\
\text { checklist and also ask students and } \\
\text { a peer observer in the classroom to } \\
\text { give feedback by filling out the } \\
\text { same checklist and then he/she } \\
\text { would look at the students and peer } \\
\text { feedback and then compare them } \\
\text { with his/her self-evaluation after } \\
\text { that, he/ she may analyze and re- } \\
\text { flect them with the received knowl- } \\
\text { edge and previous experiential } \\
\text { knowledge in order to find out ways } \\
\text { to improve his/her teaching per- } \\
\text { formance in the future }\end{array}$ & $\begin{array}{l}\text { Students' feedback } \\
\text { and peer-observer } \\
\text { feedback would be- } \\
\text { come valuable inputs } \\
\text { Using students' and } \\
\text { peer-observer feed- } \\
\text { back altogether with } \\
\text { teacher self- } \\
\text { evaluation as a tool } \\
\text { for teacher reflection } \\
\text { It may be hard to } \\
\text { evaluate oneseif } \\
\text { therefore the teacher } \\
\text { sometimes needs his/ } \\
\text { her peer to help ob- } \\
\text { serve his/her teach- } \\
\text { ing performance to } \\
\text { enrich his/her port- } \\
\text { folio }\end{array}$ \\
\hline 4 & $\begin{array}{l}\text { Teacher } \\
\text { self- } \\
\text { evaluation, } \\
\text { student's } \\
\text { feedback, } \\
\text { peer- } \\
\text { observer } \\
\text { feedback, } \\
\text { Teacher Re- } \\
\text { flection and } \\
\text { Teacher Di- } \\
\text { ary }\end{array}$ & $\begin{array}{l}\text { After a teaching session the teacher } \\
\text { would fill out the self-evaluation } \\
\text { checklist and also ask students and } \\
\text { his/her colleague to be an observer } \\
\text { in the classroom in order to give } \\
\text { feedback by filling out the same } \\
\text { checklists. After that, he/she would } \\
\text { look at the students and peer feed- } \\
\text { back and compare them with his/her } \\
\text { self-evaluation. Then, he/she has to } \\
\text { analyze and reflect them with the } \\
\text { received knowledge and previous } \\
\text { experiential knowledge in order to } \\
\text { improve his/her teaching perform- } \\
\text { ance in the classroom in the future. } \\
\text { In order to note important informa- } \\
\text { tion about the teacher's perform- } \\
\text { ance as well as the teacher's reflec- } \\
\text { tion and commitment to improve } \\
\text { his/her teaching performance, the } \\
\text { teacher may use teacher diary as a } \\
\text { tool for his/her professional devel- } \\
\text { opment. }\end{array}$ & $\begin{array}{l}\text { Students' feedback } \\
\text { and peer-observer } \\
\text { feedback would be- } \\
\text { come valuable inputs } \\
\text { Using students' and } \\
\text { peer-observer feed- } \\
\text { back altogether with } \\
\text { teacher self- } \\
\text { evaluation as a tool } \\
\text { for teacher reflection } \\
\text { It may be hard to } \\
\text { evaluate oneself } \\
\text { therefore the teacher } \\
\text { sometimes needs his' } \\
\text { her peer to help ob- } \\
\text { serve his/her teach- } \\
\text { ing performance to } \\
\text { enrich his/her port- } \\
\text { folio } \\
\text { The teacher's note is } \\
\text { a useful tool for both } \\
\text { classroom research } \\
\text { and personal profes- } \\
\text { sional development }\end{array}$ \\
\hline
\end{tabular}


Moreover, the teacher self-evaluation models could function as authentic teacher portfolios for the language teachers to show their actua efforts, progress, and achievements. In order to be authentic portfolio, the teachers have to use/implement the teacher self-evaluation models again and again within a period of time, for example, several times in one semester or one academic year. The more they try out or use them, the more information the teachers may obtain. The benefits of these self-evaluation models as portfolios for the language teachers are to control of the teachers' own teaching, to assess the teachers' own strengths and weaknesses, to encourage them to improve their teaching performance collaboratively, to help the teachers set their own realistic goals of teaching to reflect their own teaching, and to help them make decisions on their instructional plans. While the benefits of these self-evaluation models for the school principals or the heads of the departments are to asses of their teachers' achievements, to see the holistic profile of their teachers, to see the efforts as well as the progress of their teaching, to discuss their teaching processes, and strategies of their successful teaching, and to evaluate for teacher's performance for promotion.

These self-evaluation models as portfolios become rich with the evidence of what the teachers are able to do and how they are able to do it and show the individual teacher's skills, ideas, interests and accomplishments. And these long- term portfolios will provide a more accurate picture of the teacher's specific achievement and progress. By showing examples of these teachers portfolios, they provide an authentic and realistic portrait of individual teachers' abilities. And these self evaluation models always offer an opportunity for teacher self-reflection on their own best works.

\section{SURVEY}

\section{Participants}

There are forty English teachers from eighteen senior high-schools ('SMU') in Surabaya, participating in this survey. Most of these participants' academic qualifications are S1 graduates $(95 \%)$ and S2 graduates $(5 \%)$. Furthermore, there are 18 out of 146 public and private senior highschools ('SMU') taken from 5 different parts of Surabaya. And each part of Surabaya has 8 participants. And the forty participants of the survey from different schools and parts of Surabaya will be elaborated in table 2 .

Table 2. Participants of the Study

\begin{tabular}{l|c|l}
\hline $\begin{array}{c}\text { Parts of } \\
\text { Surabaya }\end{array}$ & $\begin{array}{c}\text { Member of participants } \\
\text { (English teachers) }\end{array}$ & $\begin{array}{l}\text { Senior high-schools ('SMU') taken part } \\
\text { in this survey }\end{array}$ \\
\hline Northern & 8 & $\begin{array}{l}\text { SMU Barunawati, SMU Sasana Bhakti and } \\
\text { SMUK Stella Maris }\end{array}$ \\
\hline Eastern & 8 & $\begin{array}{l}\text { SMU Dapena I, SMU Muhammadiyah 2, } \\
\text { SMUK St. Stanislaus, SMU Untag, SMU } \\
\text { YBPK I, and SMU Kr. Petra 2 }\end{array}$ \\
\hline Southern & 8 & $\begin{array}{l}\text { SMUK St. Louis 2, SMU Dharma Mulya, } \\
\text { SMUK St. Carolus, SMU Kr. Petra 1 }\end{array}$ \\
\hline Western & 8 & $\begin{array}{l}\text { SMU Kr. Gloria, SMU Kr. Kalam Kudus, } \\
\text { SMUK Karitas III }\end{array}$ \\
\hline Central & 8 & SMUN IX and SMUN V \\
\hline
\end{tabular}

\section{Procedure}

This survey was conducted between August and September 2003. There are two parts of this survey-first, we collected data from forty English teachers as participants by using an interview guide via telephones and second, we asked two volunteer English teachers from two different senior high-schools (public and private) to try out Teacher-Self Evaluation models proposed in this study. In addition, the writer also asked a colleague to do the same interview to crosscheck the consistency of the data collected by the writer himself.

\section{SURVEY RESULTS}

The results of the first survey are as follows:

(a) when asked about the feelings of satisfaction on the use of supervising checklists in order to evaluate the teacher performance given by the school principals or head of the department, the English teacher participants $(n=40)$ replied that many participants $(62.5 \%)$ did not feel satisfied but a few participants $(37.5 \%)$ felt satisfied; 
(b) when asked about self-evaluation checklists used to monitor the English teacher performance in the classroom after teaching sessions, the English teacher participants $(n=40)$ replied that most participants $(80 \%)$ never used self-evaluation checklists but only a few others $(20 \%)$ had used them;

(c) when asked about peer-observer checklists used to monitor the English teacher performance in the classroom, the English teacher participants $(n=40)$ replied that most participants $(77.5 \%)$ never used them but only a few participants $(22.5 \%)$ asked their colleagues to sit in their class in order to observe their teaching performance by using observation checklists;

(d) when asked about students' feedback checklists, all the English teacher participants $(100 \%)$ used them in order to help the teachers obtain feedback from their students on their teaching performance in the classroom;

(e) when asked about teaching reflection, some English teacher participants $(50 \%)$ used it but some others $(50 \%)$ didn't use it;

(f) when asked about teacher diary, many English teacher participants $(62.5 \%)$ used it because the school usually asked them to use it but a few other participants $(37.5 \%)$ didn't use it;

(g) when asked whether the English teacher participants wanted to use teacher self-evaluation models voluntarily, most participants $(87.5 \%)$ were willing to try them for their professional development but a few participants $(12.5 \%)$ did not want to use them because the school did not ask them to do that.

Based on the data above, we can see that

1. Many participants did not feel satisfied with the supervising checklists as an instrument to evaluate the English teacher's performance observed by the school principals in the classroom for the some reasons :

- the evaluator's educational background was not English education

- when the school principal sat in a class to observe the English teacher's performance, the classroom setting was not as natural as it was. To know their respectful person (a principal) in the class, the students usually tended to be quiet and the teacher's action might be different from the daily teaching practice

- the principal's views on the evaluation of the English teacher performance could be different from those of the English teachers themselves or the students

- the principal scores could be very subjective (different raters might give different emphasis on scoring) and sometimes they were not transparently discussed afterwards

2. All the participants had their own ways to get feedback from their students. They tried to get students' feedback because students are their main customers/audience at school. In addition, the way the English teacher got the students' feedback could be through interviews (individuals or a group of students) and questionnaires (closed or openended questionnaires)

3. Many participants $(62.5 \%)$ used teacher-diary but most of them just wrote some notes on the teaching dates and the teaching materials given, for example. some topics taken from page $\mathrm{x}$ to page $\mathrm{y}$ of a book z. They didn't mention the strengths or weaknesses of their teaching techniques or activities used in the classroom and some important parts of their teaching that should be changed or commitment to teach better in the future.

4. After knowing the benefits of using self-evaluation models for their professional development, many participants $(87.5 \%)$ wanted to try their preferred self-evaluation model voluntarily especially if their schools asked or allowed them to do. But a few participants $(12.5 \%)$ didn't want to do that because the schools didn't ask them to do so and they didn't want to make themselves busy with such additional burden.

The results of the second survey are in the forms of reports given by two volunteer English teachers from senior high-schools in Surabaya, who used self-evaluation models to monitor the teacher performance in the classroom. And the reports on the implementation of self-evaluation models will be summarized as follows :

The first report was given by RH (a part-time English teacher from SMU Kr. Petra 2 Surabaya/female/32 years old/3 years teaching experience/graduated from the faculty of letter of Gajah Mada University Jogyakarta). She chose the model using teacher self-evaluation, students' feedback, and teacher reflection. After a teaching session, she would fill 
out the self-evaluation checklist designed by Partington and Luker (1984). She would also ask her students to give feedback on her teaching performance by filling out the same checklists and then look at the students feedback and compare it with her self-evaluation. After that she analyzed both feedbacks with the received knowledge and previous experiential teaching knowledge in order to improve her teaching performance in the future. The scores of Teacher Self-Evaluation and Students' feedback could be seen in the table 3 .

Based on the data shown in the table 3, RH did reflection on her teaching performance by using reflection questions. The results of her reflections are as follows:

(a) when asked about her satisfactory feeling of her teaching, $\mathrm{RH}$ replied that she did not feel satisfied because she thought she hadn't given what the students expected. She did not feel so satisfied with shortcomings of her teaching techniques and materials due to the facts that she was not a graduate of English Teacher Training College and she only used the student textbook.

(b) when asked whether she achieved her teaching aims, she replied that most of her students understood her explanations and were eager to do some activities in class.

(c) when asked about the students' responses and their reasons for the response, she replied that some students gave good responses in doing discussion, making presentation and doing the exercises from the textbook but some others felt bored for they had to use the only textbook.

(d) when asked about aspects of the lesson she was happy with, she replied that she was happy with the reading and writing skills.

(e) when asked whether there was anything in the lesson she would like to change if she has the opportunity to do it again next time, she replied that she would like to use more media, she wanted to assign her students to obtain learning materials by using internet or from other sources such as supplement books, authentic materials (newspaper/magazines, etc), and she also wanted to use various teaching techniques.
Table 3. The scores of RH's Self Evaluation and her students' feedback by suing a self-assessment scale designed by John Partington and Patricia Luker

\begin{tabular}{|c|c|c|c|}
\hline \multirow[b]{2}{*}{ No. } & \multirow[b]{2}{*}{ Teacher performance items } & \multicolumn{2}{|c|}{ The scores of } \\
\hline & & $\begin{array}{l}\text { Self-evaluation } \\
\text { (RH) }\end{array}$ & $\begin{array}{l}\text { Students' feedback } \\
\text { (average) } n=32\end{array}$ \\
\hline 1 & Is well prepared & 2 & 3.1 \\
\hline 2 & Knows material thoroughly & 3 & 3.2 \\
\hline 3 & Enjoys teaching & 4 & 3.2 \\
\hline 4 & Speaks the language fluently & 4 & 3.2 \\
\hline 5 & $\begin{array}{l}\text { Pleased to answer students' ques- } \\
\text { tions }\end{array}$ & 4 & 3.3 \\
\hline 6 & Is dedicated & 3 & 2.9 \\
\hline 7 & $\begin{array}{l}\text { Conveys self-confidence in the lan- } \\
\text { guage }\end{array}$ & 4 & 3.3 \\
\hline 8 & Praises and encourages students & 4 & 2.8 \\
\hline 9 & $\begin{array}{l}\text { Encourages students to speak the } \\
\text { foreign language }\end{array}$ & 4 & 3.0 \\
\hline 10 & $\begin{array}{l}\text { Is positive and constructive in atti- } \\
\text { tude to teach }\end{array}$ & 4 & 3.1 \\
\hline 11 & $\begin{array}{l}\text { Explains clearly when students do } \\
\text { not understand }\end{array}$ & 4 & 2.4 \\
\hline 12 & Is enthusiastic and animated & 2 & 2.4 \\
\hline 13 & $\begin{array}{l}\text { Has practice with learning difficul- } \\
\text { ties }\end{array}$ & 4 & 3.1 \\
\hline 14 & $\begin{array}{l}\text { Goes beyond textbook. Supple- } \\
\text { ments curriculum. }\end{array}$ & 2 & 2.1 \\
\hline 15 & $\begin{array}{l}\text { Doesn't embarrass or belittle stu- } \\
\text { dents when mistakes occur }\end{array}$ & 4 & 3.7 \\
\hline 16 & Is not sarcastic or critical & 4 & 3.7 \\
\hline 17 & $\begin{array}{l}\text { Has friendly, informal, relaxed } \\
\text { classroom }\end{array}$ & 2 & 2.5 \\
\hline 18 & $\begin{array}{l}\text { Uses a great deal of variety in les- } \\
\text { son planning }\end{array}$ & 2 & 2.0 \\
\hline 19 & Accept ideas from students. Is open. & 4 & 3.0 \\
\hline 20 & $\begin{array}{l}\text { Knows when things are going } \\
\text { wrong. Flexible }\end{array}$ & 3 & 2.6 \\
\hline
\end{tabular}

Notes: The scale range from 1 (very poor) to 4 (very good)

As shown in table 3, we could see that the teacher realized her weaknesses on some items that influenced her teaching performance, that is, the lesson was not so well-prepared, her teaching was not so enthusiastic and animated, she just taught the materials from the student textbook, her 
classroom setting was not so friendly, informal and relaxed, and she didn't use variation in her teaching.

And from the students scores, we could see that the students expected her to explain more clearly, they expected her teacher to be enthusiastic and animated in her teaching and to enrich them with learning materials from other sources (beyond textbooks), they also expected her teacher to use a great deal of variation in her lesson planning, to create more friendly, informal, and relaxed classroom and to know when things were wrong. In addition the teacher was also expected to praise and encourage her students and to show her dedication.

The second report is given by AT (a full-time English teacher from "SMU Negeri IX" Surabaya/male/52 years old/about 27 years teaching experience/a M.Ed holder graduated from Exeter University in UK). He was teaching third year students (IIIP3 class) within 2 lesson-hour $(2 \times 45$ minutes). His main aim of the lesson is to find out the main ideas from a reading text. And the stages of his lesson were pre-reading (10 minutes), whilst-reading (60 minutes), and post-reading (20 minutes). In the prereading, the teacher drew students' attention by showing a picture and asked some questions relating to the picture. In the whilst-reading, the teacher asked students to do tasks individually and then in groups, and discussing the answers. In the post-reading, the teacher checked the students' answers and explained the problems. He chose the Teacher SelfEvaluation model using Teacher Self-Evaluation, Students feedback, peerobserver feedback, Teacher-Reflection and Teacher-Diary. After a teaching session, he would fill out the self-evaluation checklist designed by Partington and Luker (1984) and also asked his students (III P3 class) and AH (a full-time English teacher from "SMU Negeri IX" Surabaya/male/ \pm 35 years old/about 10 years teaching experience/an S1 graduate of Surabaya State University ) as a peer-observer in the classroom. He sat in the class and had to give feedback by filling out the same checklist. After that, he would like to see the feedback of the students and peer. Then he compared them with his self-evaluation. Next, he analyzed and reflected these three feedback with the received knowledge as well as his previous experiential knowledge in order to improve his teaching performance in the future. In order to note the important information about his teaching performance including the results of his reflection, he used a teacher diary as an instrument for professional development. The scores of his selfevaluation, students' feedback, and peer-observer feedback could be seen in table 4

Further, AH, a peer-observer gave his general comments on AT's teaching performance. There were 2 comments-positive points and suggestions. In the positive points, $\mathrm{AH}$ stated that AT was well-experienced English teacher. And the observer had to learn many things from AT. He also observed that the students enjoyed his lesson. Furthermore, he suggested that AT should speak more slowly because some students were poor in their English lesson.

Based on the data shown in the table 4, AT conducted reflection on his teaching performance by using reflection questions. The results of his reflection are as follows.

(a) when asked about his satisfactory feelings of his teaching at class III P3 on August 20, 2003, AT replied that he felt satisfied in some ways. He didn't feel satisfied with the materials taken from the textbook which contains too many difficult words for his students so that his students tempted to use the dictionary too often though they didn't need to know the meanings of all difficult words.

(b) when asked whether he achieved his teaching goals, he replied that there was clear evidence that students understood the objective of the lesson and he could see this from the students' responses

(c) when asked about the students' responses on the activities, he replied that his students gave good responses on the activities because they knew what were expected from them.

(d) when asked about aspects of the lesson he was happy with, he replied that he was happy with his students' responses. The students were active and asked many questions.

(e) when asked whether there was anything in the lesson that he would change if he had the opportunity to do it again, he replied that he was going to find out more suitable materials which correspond with the level of his students knowledge and skills. 
Table 4. The scores of AT's self-evaluation, III P3 students' feedback ( $n=36$ ), and peer-observer feedback by using a self-assessment scalc designed by John Partington and Patricia Luker (1984)

\begin{tabular}{|c|c|c|c|c|}
\hline \multirow[b]{2}{*}{ No. } & \multirow[b]{2}{*}{$\begin{array}{c}\text { Teacher performance } \\
\text { items }\end{array}$} & \multicolumn{3}{|c|}{ The scores of } \\
\hline & & $\begin{array}{c}\text { Self- } \\
\text { evaluation } \\
\text { (AT) }\end{array}$ & $\begin{array}{c}\text { Students' } \\
\text { feedback } \\
\text { (average) } \\
n=36\end{array}$ & $\begin{array}{l}\text { Peer-observation } \\
\text { feedback } \\
\text { (AH) }\end{array}$ \\
\hline 1 & Is well prepared & 4 & 3.3 & 4 \\
\hline 2 & $\begin{array}{l}\text { Knows material thor- } \\
\text { oughly }\end{array}$ & 4 & 3.9 & 4 \\
\hline 3 & Enjoys teaching & 3 & 3.5 & 4 \\
\hline 4 & $\begin{array}{l}\text { Speaks the language flu- } \\
\text { ently }\end{array}$ & 4 & 4.0 & 4 \\
\hline 5 & $\begin{array}{l}\text { Pleased to answer stu- } \\
\text { dents' questions }\end{array}$ & 4 & 3.8 & 4 \\
\hline 6 & Is dedicated & 3 & 3.5 & 4 \\
\hline 7 & $\begin{array}{l}\text { Conveys self-confidence } \\
\text { in the language }\end{array}$ & 4 & 4.0 & 4 \\
\hline 8 & $\begin{array}{l}\text { Praises and encourages } \\
\text { students }\end{array}$ & 4 & 3.2 & 3 \\
\hline 9 & $\begin{array}{l}\text { Encourages students to } \\
\text { speak the foreign lan- } \\
\text { guage }\end{array}$ & 4 & 3.6 & 3 \\
\hline 10 & $\begin{array}{l}\text { Is positive and construc- } \\
\text { tive in attitude to teach }\end{array}$ & 4 & 3.5 & 4 \\
\hline 11 & $\begin{array}{l}\text { Explains clearly when } \\
\text { students do not under- } \\
\text { stand }\end{array}$ & 4 & 3.2 & 4 \\
\hline 12 & $\begin{array}{l}\text { Is enthusiastic and ani- } \\
\text { mated }\end{array}$ & 4 & 3.7 & 4 \\
\hline 13 & $\begin{array}{l}\text { Has practice with learning } \\
\text { difficuities }\end{array}$ & 4 & 3.4 & 4 \\
\hline 14 & $\begin{array}{l}\text { Goes beyond textbook. } \\
\text { Supplements curriculum }\end{array}$ & 4 & 3.0 & 4 \\
\hline 15 & $\begin{array}{l}\text { Doesn't embarrass or be- } \\
\text { little students when mis- } \\
\text { takes occur }\end{array}$ & 4 & 3.7 & 4 \\
\hline 16 & Is not sarcastic or critical & 4 & 3.4 & 4 \\
\hline 17 & $\begin{array}{l}\text { Has friendly, informal, } \\
\text { relaxed classroom }\end{array}$ & 4 & 3.7 & 4 \\
\hline 18 & $\begin{array}{l}\text { Uses a great deal of vari- } \\
\text { ety in lesson planning }\end{array}$ & 4 & 3.7 & 4 \\
\hline
\end{tabular}

\begin{tabular}{c|l|c|c|c}
\hline 19 & $\begin{array}{l}\text { Accept ideas from stu- } \\
\text { dents. Is open. }\end{array}$ & 4 & 3.5 & 4 \\
\hline 20 & $\begin{array}{l}\text { Knows when things are } \\
\text { going wrong. Flexible }\end{array}$ & 4 & 3.0 & 4 \\
\hline
\end{tabular}

Notes : a scale range from 1 (very poor) to 4 (very good)

After AT had done reflection on the data above, he noted necessary points in his teacher diary in order to achieve his best performance. From the students feedback, there are things that could be improved such as the teacher should go beyond textbook, know when things are going wrong, praise and encourage students, and explain clearly when students do not understand. From the peer observer feedback, the teacher could praise and encourage students more and also encourage students to speak English.

Furthermore, some comments on the data collected by AT at class III P3 on August 20, 2003 are as follows

1. By eyeballing AT's self-evaluation scores and the students' average scores on his teaching performance, most of his self-evaluation scores are higher than his students' average scores.

2. Almost all the items of the self-evaluation meet the highest score $=4$ which means very good except two of the items-enjoys teaching and is dedicated-haven't achieved the highest score. This means that there is still an opportunity for him to upgrade these parts of his teaching performance so that the teacher himself will fully enjoy his teaching and be able to do his best.

3. From the students' average scores, we can see that they gave at least the average score $=3$. This means all the items are at least good scores and many of them reach to very good scores. Even some of the students' average scores approximately simulate to the teacher selfevaluation scores, namely, conveys self-confidence, knows materials thoroughly, and speaks English fluently. Based on the students scores, the teacher could upgrade some items of the teaching performance, such as goes beyond the textbook, supplements curriculum, knows when things are wrong, and makes better preparation in order to achieve the highest scores based on the students' views.

4. The peer observer gave the same scores as the teacher self-evaluation. In other words, the peer-observer scores corresponds with the teacher 


\section{self-evaluation scores}

Besides class III P3, AT also used the self-evaluation model to monitor his teaching performance in class III P4 on the same date (August 20, 2003) with another peer observer, Sri Ningsih (a full-time English teacher of "SMU Negeri IX" Surabaya/female/42 years old/about 15 years teaching experience/an SI graduate of Teacher Training College in English Education)

In class III P 4, AT was teaching communicative activities within 2 lesson hours ( $2 \times 45$ minutes). The aim of his teaching was to develop students' skill in building up grammatical and semantical sentences by the use of scrabble game. The stages of his teaching lesson were the preactivity (10 minutes) where he explained clearly what students must do and he also explained about the objective of the lesson, the main activities (70 minutes) where students were playing a scrabble game and the teacher just monitored and gave some help if needed, and the post-activity (10 minutes) where he collected all the works and he would solve the problems together at the next meeting.

After this session, AT filled out his self-evaluation checklist and also asked his students to give feedback on his teaching performance by filling out the same assessment checklist. During the session, he also asked his colleague, SN to observe his classroom by sitting in the class and filling out the same assessment checklist. And the scores of his self-evaluations, students' feedback, and peer-observers' feedback could be seen in table 5 .

Based on the data shown in the table 5, AT conducted reflection on his teaching performance by using reflection questions. The results of his reflection are as follows

(a) when asked about his satisfactory feeling of his teaching at class III P 4 on August 20, 2003, AT replied that he felt satisfied because the students enjoyed his lesson and more than $85 \%$ of the students in that session were able to write good sentences;

(b) when asked whether he achieved his teaching goals, he replied that from the works the students handed in to him, they were aware of what was expected from them;

(c) when asked about the students' responses to the activities, he replied that the students were happy and realized that English lesson could be fun and at the same time develop their language skills
Table 5. The scores of AT's Self Evaluation, III P4 students' feedback ( $=35$ ), and peer-observer feedback by using a self-assessment scale designed by Partington and Luker (1984)

\begin{tabular}{|c|c|c|c|c|}
\hline \multirow[b]{2}{*}{ No. } & \multirow[b]{2}{*}{ Teacher Performance Items } & \multicolumn{3}{|c|}{ The scores of } \\
\hline & & $\begin{array}{c}\text { Self-Evalua- } \\
\text { tion } \\
\text { (AT) }\end{array}$ & 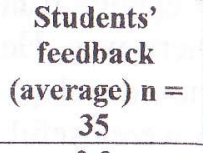 & $\begin{array}{c}\text { Peer- } \\
\text { Observer } \\
\text { feedback } \\
\text { (SN) }\end{array}$ \\
\hline 1 & Is well prepared & 4 & 3.3 & 4 \\
\hline 2 & Knows material thoroughly & 4 & 3.9 & 4 \\
\hline 3 & Enjoys teaching & 3 & 3.4 & 3 \\
\hline 4 & Speaks the language fluently & 4 & 3.9 & 4 \\
\hline 5 & $\begin{array}{l}\text { Pleased to answer students' } \\
\text { questions }\end{array}$ & 4 & 3.7 & 4 \\
\hline 6 & Is dedicated & 3 & 3.5 & 3 \\
\hline 7 & $\begin{array}{l}\text { Conveys self-confidence in the } \\
\text { language }\end{array}$ & 4 & 4.0 & 4 \\
\hline 8 & $\begin{array}{l}\text { Praises and encourages stu- } \\
\text { dents }\end{array}$ & 4 & 3.3 & 4 \\
\hline 9 & $\begin{array}{l}\text { Encourages students to speak } \\
\text { the foreign language }\end{array}$ & 4 & 3.7 & 4 \\
\hline 10 & $\begin{array}{l}\text { Is positive and constructive in } \\
\text { attitude to teach }\end{array}$ & 4 & 3.5 & 4 \\
\hline 11 & $\begin{array}{l}\text { Explains clearly when students } \\
\text { do not understand }\end{array}$ & 4 & 3.5 & 4 \\
\hline 12 & Is enthusiastic and animated & 4 & 3.7 & 4 \\
\hline 13 & $\begin{array}{l}\text { Has practice with learning dif- } \\
\text { ficulties }\end{array}$ & 4 & 3.5 & 4 \\
\hline 14 & $\begin{array}{l}\text { Goes beyond textbook. Sup- } \\
\text { plements curriculum. }\end{array}$ & 4 & 3.0 & 4 \\
\hline 15 & $\begin{array}{l}\text { Doesn't embarrass or belittle } \\
\text { students when mistakes occur }\end{array}$ & 4 & 3.6 & 4 \\
\hline 16 & Is not sarcastic or critical & 4 & 3.3 & 4 \\
\hline 17 & $\begin{array}{l}\text { Has friendly, informal, relaxed } \\
\text { classroom }\end{array}$ & 4 & 3.6 & 4 \\
\hline 18 & $\begin{array}{l}\text { Uses a great deal of variety in } \\
\text { lesson planning }\end{array}$ & 4 & 3.7 & 4 \\
\hline 19 & $\begin{array}{l}\text { Accept ideas from students. Is } \\
\text { open. }\end{array}$ & 4 & 3.6 & 4 \\
\hline 20 & $\begin{array}{l}\text { Knows when things are going } \\
\text { wrong. Flexible }\end{array}$ & 4 & 3.1 & 4 \\
\hline
\end{tabular}


(d) when asked about aspects of the lesson he was happy with, he replied that he was happy with almost all aspects of the lesson except some weaker students might make him sad

(e) when asked whether there was anything in the lesson that he would change if he had the opportunity to do it again, he replied that there was. He always tried to do things that could help his students develop their English by collecting more materials which were useful for communication activities.

After AT had done reflection by using data above, he noted some important points in his teacher diary in order to improve his performance From the students' feedback, there were things that could be improved such as the teacher should go beyond textbook, know when things are going wrong, be well-prepared, praise and encourage students, and not be so sarcastic or critical and so on.

The comments on the data collected by AT on his teaching at class III P4 on August 20,2003 are as follows

1. By eyeballing AT's self-evaluation scores and the students average scores on his teaching performance, most of his selfevaluation scores are higher than the students' average scores.

2. Almost all the items of the self-evaluation meet the highest score $=4$ meaning very good except two of the items - enjoys teaching and is dedicated - haven't achieved the highest score. This means that there is still an opportunity for him to upgrade these parts of his performance so that the teacher himself will be fully enjovable in his teaching and show his best dedication as a teacher who could do his best.

3. As seen in the students' average scores, we can see the students gave at least the average score 3 . This means that all items are at least good scores and many of them could reach to very good scores. Even some of the students average scores approximately simulate to the teacher self-evaluation scores such as speaks English fluently, conveys self-confidence, knows the materials thoroughly, and pleased to answer students 'questions. Based on the students' scores, the teacher could upgrade some items of his teaching performance, for example goes beyond textbook, knows when things are going wrong, praises and encourages students, and explains clearly when students do not understand

The peer observer gave almost the same scores as the teacher selfevaluation. In peer-observer opinion, most of the teacher performance were already very good (score 4) except the teacher had to upgrade two items-praises and encourages students to speak English-in order to achieve the highest score $=4$.

\section{CONCLUSION}

1. There are some teacher self-evaluation models used to monitor language teachers' performance in the classroom so that the teachers could improve their own teaching performance for their professional development.

2. The instruments of the teacher self-evaluation models are the teacher self-evaluation checklist, the students' feedback checklist, the peer-observer feedback checklist, the teacher reflection and the teacher diary. And the teachers may choose their own alternative models and use these instruments several times so that they could see the progress or achievements by showing their efforts of using their self-evaluation models as authentic portfolio within a period of time (within one semester or one academic year).

3. The teacher self-evaluation models as authentic portfolio are beneficial for the teachers to control their own teaching, to assess their own strengths and weaknesses in their own teaching, to help them identify and set their own realistic goals of teaching, and to help them make decisions on their teaching plans.

4. These models also show the teachers' efforts, progress, and achievements as well as the teachers' holistic teaching performance in the classroom and help them to be collaborative and reflective teachers.

5. The teacher self-evaluation models as authentic portfolio are also beneficial for the school principals or the head of the department to know what the teachers have accomplished, to help their teachers realize the problematic aspects of the teacher performance, to understand their teachers' motivation, interest, strengths and weaknesses, to see the teachers' profile of their teaching 
performance, to improve their teacher instructional plans, to praise teachers for their effective teaching strategies/techniques, and to evaluate the teachers' performance for promotion.

6. Teacher self-evaluation models facilitate the teachers to be selfdirected learners and affect their schools to create self-learning atmosphere for professional development.

7. These self-evaluation models as portfolios also help the teachers realize their own weaknesses and their students' needs in order to encourage the teachers to change their unsuccessful ways of teaching or try out the other new ways so that they could find out the best solution for the problematic aspects of their teaching performance in the classroom. These will raise their awareness of their own teaching performance, motivate them to conduct action research on their classroom problems, and enhance the quality of their teaching performance in the classroom. In other words, the teacher portfolio helps teachers become more aware of what they are doing in the classroom and also help them be sell-reflective about their own work.

\section{REFERENCES}

Allwright. Dick. 1998. Learning to Teach. Fourth Edition. Singapore: McGrawHill

Elliot. J. 1991. Action Research for Educational Change. Philadelphia: Open University Press.

Gibbs, Graham and Habeshaw, Trever.1989. Preparing to teach. First edition. Bristol: Teaching and Educational Services.

Halbach, Ana. 1999. Using Trainee Diaries to Evaluate Teachers Training Course. Printed in ELT Journal Volume 53/3 July 1999. Oxford: Oxford University Press.

Jones, Margest Cameron. 1991. Training Teachers, UK: Bell and Bain

Wallace, MJ. 1993. Training Foreign Language Teachers. Cambridge. University Press.

\section{APPENDIX 1}

First Model Designed by

Teacher's Name: .......................... Gibbs \& Habeshaw (1989)

Date

Self-Evaluation Checklist

For English Teacher After a Teaching Session

\begin{tabular}{|c|c|c|c|c|c|}
\hline How well did I..........? & $\begin{array}{l}\text { Very } \\
\text { Well }\end{array}$ & $\begin{array}{l}\text { Satisfac- } \\
\text { tory }\end{array}$ & $\begin{array}{l}\text { Not Very } \\
\text { Well }\end{array}$ & Poorly & $\begin{array}{c}\text { Not } \\
\text { Relevant }\end{array}$ \\
\hline \multicolumn{6}{|l|}{ 1. Link this session to other sessions } \\
\hline \multicolumn{6}{|l|}{ 2. Introduce this session } \\
\hline \multicolumn{6}{|l|}{$\begin{array}{l}\text { 3. Make the aims clear to the stu- } \\
\text { dents }\end{array}$} \\
\hline \multicolumn{6}{|l|}{ 4. Move clearly from stage to stage } \\
\hline \multicolumn{6}{|l|}{ 5. Emphasise key points } \\
\hline \multicolumn{6}{|l|}{ 6. Summarise the session } \\
\hline \multicolumn{6}{|l|}{ 7. Maintain an appropriare pace } \\
\hline \multicolumn{6}{|l|}{ 8. Capture students' interest } \\
\hline \multirow{2}{*}{\multicolumn{6}{|c|}{ 9. Maintain students' interest }} \\
\hline \multirow{2}{*}{\multicolumn{4}{|c|}{$\begin{array}{l}\text { 10. Handle problems of inattention } \\
\text { 11. Ask questions }\end{array}$}} & & \\
\hline \multicolumn{3}{|l|}{ 11. Ask questions } & & & \\
\hline \multicolumn{6}{|l|}{$\begin{array}{l}\text { 12. Handle student questions and } \\
\text { responses }\end{array}$} \\
\hline \multicolumn{6}{|l|}{ 13. Direct student tasks } \\
\hline \multicolumn{6}{|l|}{ 14. Cope with the range of ability } \\
\hline \multicolumn{6}{|l|}{ 15. Monitor student activity } \\
\hline \multicolumn{6}{|l|}{ 16. Use aids as illustrations } \\
\hline \multicolumn{6}{|l|}{$\begin{array}{l}\text { 17. Make contact with all class } \\
\text { members }\end{array}$} \\
\hline \multicolumn{6}{|l|}{ 18. Cope with individual difficulties } \\
\hline \multicolumn{6}{|l|}{ 19. Keep the material relevant } \\
\hline \multicolumn{6}{|l|}{$\begin{array}{l}\text { 20. Use my voice and body move- } \\
\text { ments }\end{array}$} \\
\hline \multicolumn{6}{|l|}{ 21. Check on student learning } \\
\hline \multicolumn{6}{|l|}{ 22. Build up student confidence } \\
\hline 23. Convey my enthusiasm & & & & & \\
\hline $\begin{array}{l}\text { 24. Provide a model of good prac- } \\
\text { tice }\end{array}$ & & & & & \\
\hline
\end{tabular}




\section{APPENDIX 2}

Second Model Designed by Jones (1991)

Teacher's Name

Date

\section{Self-Evaluation Checklist}

\section{For English Teacher After a Teaching Session}

\begin{tabular}{|c|c|c|c|c|}
\hline No & FOCUS & TARGET & GRADE & COMMENTS \\
\hline 1. & $\begin{array}{l}\text { The teacher's } \\
\text { knowledge of } \\
\text { the subject }\end{array}$ & $\begin{array}{l}\text { A sound knowledge of con- } \\
\text { tent was evident in every as- } \\
\text { pect/phrase of the teaching. }\end{array}$ & $\mathrm{ABCD}$ & \\
\hline 2. & $\begin{array}{l}\text { The way the } \\
\text { teacher struc- } \\
\text { tured the in- } \\
\text { formation. }\end{array}$ & $\begin{array}{l}\text { The content was structured } \\
\text { and sequenced appropriately } \\
\text { for pupils, within and be- } \\
\text { tween the successive phrase } \\
\text { of teaching and learning. }\end{array}$ & $\mathrm{ABCD}$ & \\
\hline 3. & $\begin{array}{l}\text { The way the } \\
\text { teacher ex- } \\
\text { plained and } \\
\text { presented the } \\
\text { content. }\end{array}$ & $\begin{array}{l}\text { The explanations given were } \\
\text { clear. Examples, illustrations } \\
\text { and tasks presented to pupils } \\
\text { were valid for the underlying } \\
\text { principles/concepts of the } \\
\text { content and for the skills to be } \\
\text { learned by the pupils. }\end{array}$ & $\mathrm{ABCD}$ & \\
\hline 4. & $\begin{array}{l}\text { The teacher's } \\
\text { questioning } \\
\text { and other } \\
\text { elicitation of } \\
\text { pupil re- } \\
\text { sponses. }\end{array}$ & $\begin{array}{l}\text { The elicitation methods used } \\
\text { (verbal including questioning, } \\
\text { and also non-verbal) were ap- } \\
\text { propriate for the facilitation } \\
\text { and progression of leaming. }\end{array}$ & $\mathrm{ABCD}$ & \\
\hline 5. & $\begin{array}{l}\text { The teacher's } \\
\text { responsiveness } \\
\text { and rapport } \\
\text { with the pupils. }\end{array}$ & $\begin{array}{l}\text { The responses given to } \\
\text { pupils' work/ideas/activities/ } \\
\text { selves were valid and encour- } \\
\text { aging }\end{array}$ & $\mathrm{ABCD}$ & \\
\hline 6. & $\begin{array}{l}\text { The way the } \\
\text { teacher resour- } \\
\text { ced the lesson. }\end{array}$ & $\begin{array}{l}\text { The resources for teaching, } \\
\text { learning, etc, were suitably } \\
\text { deployed. }\end{array}$ & $A B C D$ & \\
\hline
\end{tabular}

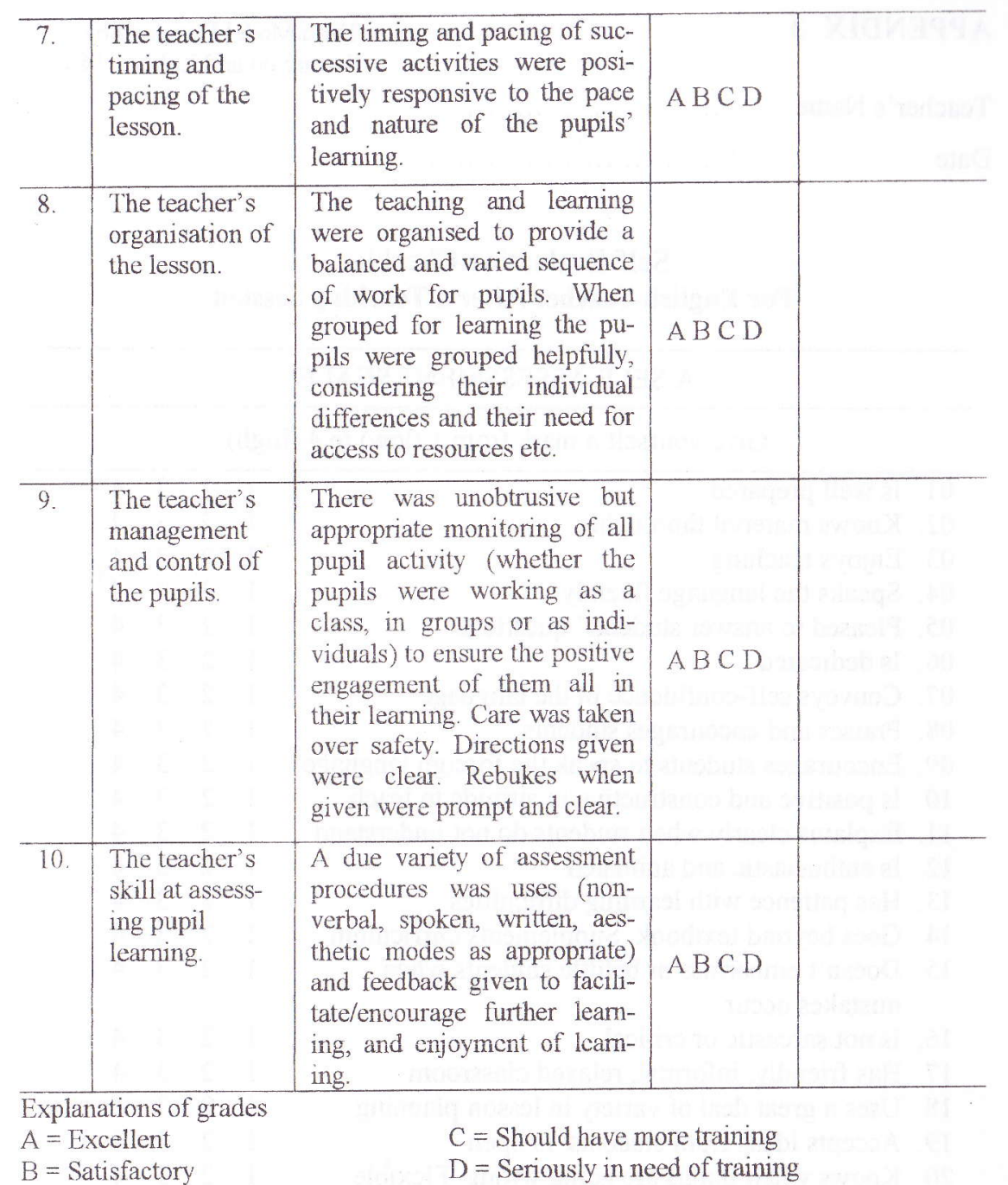




\section{APPENDIX 3}

Third Model Designed by

Partington and Luker (1984)

Teacher's Name

: $\ldots \ldots+\ldots \ldots+\ldots+\ldots \ldots+\ldots$

Date

:...........................

Self-Evaluation Checklist

For English Teacher After a Teaching Session

\section{A SELF-ASSESSMENT SCALE}

Give yourself a mark from 1 (low) to 4 (high)

01. Is well prepared

$\begin{array}{llll}1 & 2 & 3 & 4\end{array}$

02. Knows material thoroughly

03. Enjoys teaching

04. Speaks the language fluently

$\begin{array}{lll}2 & 3 & 4\end{array}$

05. Pleased to answer students' questions

$\begin{array}{llll}1 & 2 & 3 & 4\end{array}$

06. Is dedicated

07. Conveys self-confidence in the language

$\begin{array}{lll}2 & 3 & 4\end{array}$

$\begin{array}{llll}1 & 2 & 3 & 4\end{array}$

08. Praises and encourages students

09. Encourages students to speak the foreign language

10. Is positive and constructive in attitude to teach.

$\begin{array}{llll}1 & 2 & 3 & 4\end{array}$

$\begin{array}{llll}1 & 2 & 3 & 4\end{array}$

11. Explains clearly when students do not understand $1 \begin{array}{llll}1 & 2 & 3 & 4\end{array}$

12. Is enthusiastic and animated $\quad 1 \quad 2 \quad 3 \quad 4$

13. Has patience with learning difficulties $\quad 1 \quad 2 \quad 3 \quad 4$

14. Goes beyond textbook. Supplements curriculum $\quad \begin{array}{llll}1 & 2 & 3 & 4\end{array}$

15. Doesn't embarrass or belittle students when $\quad 1 \quad 2 \quad 3 \quad 4$ mistakes occur

16. Is not sarcastic or critical

17. Has friendly, informal, relaxed classroom

18. Uses a great deal of variety in lesson planning

19. Accepts ideas from students. Is open

20. Knows when things are going wrong. Flexible 